\title{
Concurrent Strength and Endurance Training
}

\author{
Jason Williams* \\ Doctoral Teaching Assistant, United States Sports Academy, One Academy Drive, USA
}

Submission: November 30, 2017; Published: December 11, 2017

*Corresponding author: Jason Williams, Doctoral Teaching Assistant, United States Sports Academy, One Academy Drive, Daphne, US, Tel: +1-251-626-3303; Fax: +1-251-625-1035; Email: jjwilliams@ussa.edu

\section{Abstract}

These data support reducing volume during periods of CT. Two and three-week training days seem to have a greater frequency of success when compared to four, five, and six day studies. Though not all higher volume programs attenuated strength, many did, leaving exercise practitioners a warning to program volume in CT periods with caution. Also, scheduling RT work before END work has proven a successful method. These data are encouraging for exercise practitioners who need to augment simultaneous physical qualities to compete in their respective sports. This article reviewed 19 concurrent training (CT) studies that simultaneously sought to increase strength and endurance qualities.

\section{Introduction}

Concurrent training (CT) is the simultaneous physical preparation of two or more exercise modalities. Common combinations include strength and power, hypertrophy and strength, and power and power endurance. The combination of strength and endurance (END) is common, but the efficacy of such a combination has conflicting findings. END can be defined as maximal oxygen consumption (VO2 Max) for END athletes and anaerobic power output (for field sport athletes). The purpose of this review is to discuss the abundance of research for and against the concurrent training of strength and END. A total of 19 CT studies were analyzed. The results are listed in Table 1. Based on the results, it can be inferred that CT training can be used successfully in training regimes to simultaneously improve multiple physiological qualities, namely strength, and END. However, research indicates that lower training volumes are needed. Also, completing resistance training (RT) work prior to END work is necessary to improve both END and strength simultaneously.

Table 1: Defines length of study, population used, resistance training (RT) variables mentioned, endurance (END) variables mentioned, volume (training duration and/or training frequency, and results).

\begin{tabular}{|c|c|c|c|c|c|}
\hline Researchers \& Length & Population & RT Method & END Method & Volume & Results \\
\hline Alves et al. [6] & 168 & Twice weekly & Twice weekly & Low & $\begin{array}{l}\text { CT augmented power } \\
\text { movements (med ball } \\
\text { throws, vertical jumps) }\end{array}$ \\
\hline 8 weeks & $\begin{array}{l}\text { 10-11 year old } \\
\text { children }\end{array}$ & $\begin{array}{l}\text { Med ball throw, box } \\
\text { jumps, } 30-40 \text { meter } \\
\text { sprints }\end{array}$ & 20-meter shuttle runs & & \\
\hline Bell et al. [10] & $\begin{array}{c}23+\text { years old; } \\
\text { physically active }\end{array}$ & $\begin{array}{c}3 \text { days a week; } 1 \\
\text { isokinetic exercise } \\
\text { at max effort for } 30 \\
\text { seconds }\end{array}$ & $\begin{array}{l}\text { Cycle ergometer; } 5 \\
\text { sets of } 5 \text { at } \mathrm{VO}^{2} \text { Peak }\end{array}$ & $\begin{array}{c}6 \text { days a week; } \\
\text { High }\end{array}$ & $\begin{array}{l}\text { CT was inferior to RT } \\
\text { alone }\end{array}$ \\
\hline Davis, et al. [7] & 28 women & $\begin{array}{l}3 \text { days a week Two } \\
\text { groups: Group } 1 \text { - RT } \\
\text { at low heart rates. } \\
\text { Group 2: RT at high } \\
\text { heart rate. }\end{array}$ & $\begin{array}{c}\text { Both groups } \\
\text { performed } \\
\text { subsequent aerobic } \\
\text { sessions. } 30 \text { minutes } \\
\text { of vigorous treadmill } \\
\text { running. }\end{array}$ & 3 - Moderate & $\begin{array}{c}\text { Increases in lower } \\
\text { body strength } \\
(17.2 ; 23.3 \%) \text {, upper } \\
\text { body strength (19\%; } \\
\text { 17.8) and fat free mass } \\
(1.8 ; 3.3) \text { were seen } \\
\text { in both groups. CT did } \\
\text { not interfere. }\end{array}$ \\
\hline
\end{tabular}


Journal of Physical Fitness, Medicine \& Treatment in Sports

\begin{tabular}{|c|c|c|c|c|c|}
\hline 11 weeks & Average age of 28 & $\begin{array}{l}3 \text { circuit sets (e.g. } \\
\text { bench, lat pull down) } \\
\text { Total of } 9 \text { exercises }\end{array}$ & & & \\
\hline $\begin{array}{l}\text { Chtara et al. [2] } \\
12 \text { weeks }\end{array}$ & $\begin{array}{l}48 \text { students; Mean } \\
\text { age of } 21\end{array}$ & $\begin{array}{c}\text { Circuit Training } \\
\text { Weeks } 1 \text { - } 6 \text { muscle } \\
\text { endurance was } \\
\text { trained } \\
\text { Weeks } 7-12 \text { Power } \\
\text { was trained. Twice } \\
\text { weekly }\end{array}$ & $\begin{array}{c}\text { Group } 1 \text { - END before } \\
\text { RT } \\
\text { Group } 2 \text { RT before } \\
\text { END } \\
\text { Group } 3 \text { - No END } \\
\text { *5 repetition runs at } \\
60 \% \text { VO2 max. }\end{array}$ & Low & $\begin{array}{l}\text { CT interfered with } \\
\text { strength gains. No } \\
\text { significant differences } \\
\text { existed between Group } \\
1 \text { and } 2 \text { but did exist in } \\
\text { comparison to RT only }\end{array}$ \\
\hline $\begin{array}{l}\text { Gravelle \& Blessing [10] } \\
\qquad 11 \text { weeks }\end{array}$ & 19 women & $\begin{array}{l}3 \text { x times weekly } \\
5-6 \text { lower body } \\
\text { exercises for } 45 \\
\text { minutes }\end{array}$ & $\begin{array}{c}3 \times \text { weekly; } 45 \\
\text { minutes of rowing at } \\
75 \% \text { VO2 Max } \\
\text { Group } 1 \text { - END After } \\
\text { RT } \\
\text { Group } 2 \text { - END before } \\
\text { RT } \\
\text { Group } 3 \text { - No END }\end{array}$ & Moderate & $\begin{array}{l}\text { CT did not interfere } \\
\text { with strength training. } \\
\text { No differences in } 1 \text { rep } \\
\text { max existed. Greater } \\
\text { aerobic improvements } \\
\text { were seen in group } 1 .\end{array}$ \\
\hline Hennessy \& Watson [11] & Unspecified & $\begin{array}{l}3 \text { Days a Week } \\
\text { Unspecified }\end{array}$ & $\begin{array}{c}\text { Group } 1 \text { - No END } \\
\text { Group } 2 \text { - } 2 \text { days a } \\
\text { week } \\
\text { Unspecified }\end{array}$ & 5 - High & $\begin{array}{l}\text { Similar gains in upper } \\
\text { body strength were } \\
\text { made in CT group but } \\
\text { compromised gains } \\
\text { in the lower body } \\
\text { (Strength and power). }\end{array}$ \\
\hline Hakkinen et al. [13] & $\begin{array}{l}38+\text { year old } \\
\text { men; moderately } \\
\text { sedentary }\end{array}$ & $\begin{array}{l}2 \text { days a week; } 6-7 \\
\text { exercises, } 50-80 \% \text {, } \\
\text { 8-12 reps. }\end{array}$ & $\begin{array}{c}2 \text { days a week; First } 7 \\
\text { weeks light cycling or } \\
\text { walking for up to } 30 \\
\text { minutes. Weeks } 8-14 \\
\text { times increased to } \\
60-90 \text { min. }\end{array}$ & 4; high & $\begin{array}{l}\text { CT yielded similar } \\
\text { strength gains }\end{array}$ \\
\hline Hickson [3] & $\begin{array}{l}\text { Mean age of } 26 ; \\
\text { physically active }\end{array}$ & $\begin{array}{l}5 \text { days a week; } 2-3 \\
\text { exercises, } 80 \% \\
\text { intensity of } 1 \mathrm{RM}, 3-5 \\
\text { sets, 5-20 reps }\end{array}$ & $\begin{array}{l}\text { Cycle ergometer, } \\
\text { and running, 30-40 } \\
\text { minutes near VO2 } \\
\text { max; } 6 \text { days }\end{array}$ & $\begin{array}{c}6 \text { days; Extremely } \\
\text { High }\end{array}$ & $\begin{array}{c}\text { CT was inferior to RT } \\
\text { alone. }\end{array}$ \\
\hline Izquierdo et al. [12] & $43+$ year old men & $\begin{array}{l}\text { Unspecified; one day } \\
\text { a week }\end{array}$ & $\begin{array}{l}\text { Unspecified; one day } \\
\text { a week }\end{array}$ & 1-2 days; Low & $\begin{array}{l}\text { CT yielded similar } \\
\text { gains in first } 8 \text { weeks. } \\
\text { However, prolonged } \\
\text { training saw drops } \\
\text { in strength in the CT } \\
\text { group. }\end{array}$ \\
\hline $\begin{array}{c}\text { Jones et al. [4] } \\
6 \text { weeks }\end{array}$ & $\begin{array}{l}24 \text { healthy men } \\
\text { with }>2 \text { years of } \\
\text { experience of RT } \\
\text { (Mean age 25). }\end{array}$ & $\begin{array}{c}\text { 5-6 reps of max } \\
\text { voluntary isometric } \\
\text { contraction } \\
\text { Group } 1 \text { - } 3 \text { days of RT } \\
\text { Group } 2 \text { - } 1 \text { day of RT } \\
\text { Group } 3 \text { - } 3 \text { days of RT }\end{array}$ & $\begin{array}{c}\text { Group } 1 \text { - } 1 \text { day of } \\
\text { END } \\
\text { Group } 2 \text { - } 1 \text { day of } \\
\text { END } \\
\text { Group } 3 \text { - No END } \\
30 \text { minutes of } \\
\text { repeated isokinetic } \\
\text { unilateral leg } \\
\text { extensions }\end{array}$ & Moderate & $\begin{array}{l}\text { CT interfered with } \\
\text { strength development }\end{array}$ \\
\hline $\begin{array}{c}\text { Jones et al. [4] } \\
6 \text { weeks }\end{array}$ & $\begin{array}{l}30 \text { RT trained men } \\
\text { Mean age of } 23\end{array}$ & $\begin{array}{c}\text { Group } 1 \text { - } 3 \text { days of RT } \\
\text { Group } 2 \text { - } 3 \text { days of RT } \\
\text { Group } 3 \text { - } 1 \text { day of RT } \\
\text { Weeks 1-4: } 3 \text { sets of } \\
10 @ 70 \% \\
\text { Week 4-6: } 4 \text { sets of } 8 \\
\text { @80\% }\end{array}$ & $\begin{array}{c}\text { Group } 1 \text { - No END } \\
\text { Group } 2 \text { - } 1 \text { day END } \\
\text { Group } 3 \text { - } 1 \text { day END } \\
\text { Immediately after RT } \\
\text { - } 1 \% \text { treadmill incline } \\
\text { at } 70 \% \text { of VO2 }\end{array}$ & Moderate & $\begin{array}{l}\text { CT interferes with } \\
\text { strength (especially } \\
\text { lower body strength } \\
\text { and power) }\end{array}$ \\
\hline
\end{tabular}




\begin{tabular}{|c|c|c|c|c|c|}
\hline Karavirta et al. [5] & $\begin{array}{l}\text { 40-67-year-old } \\
\text { men (mean 56); } \\
\text { sedentary }\end{array}$ & $\begin{array}{c}\text { Twice a week; 7-10 } \\
\text { exercises; Multiple } \\
\text { phases - light cycle } \\
\text { (40-60\%, } 12-20 \text { reps, } \\
3 \text { sets), } 2 \text { nd cycle - } \\
\text { (60-80\%, 5-12 reps, } \\
\text { 2-4 sets). 3rd cycle } \\
\text { - (70-85\%, 5-8 reps, } \\
2-4 \text { sets) }\end{array}$ & $\begin{array}{l}\text { Twice a week; First } \\
7 \text { weeks on bicycle } \\
\text { ergometer for } 30 \\
\text { min below aerobic } \\
\text { threshold; last } 7 \\
\text { weeks, } 45-90 \text { sessions } \\
\text { at high intensity }\end{array}$ & 4 days a week; high & $\begin{array}{l}\text { Gains in strength } \\
\text { were similar but } \\
\text { hypertrophy was } \\
\text { interrupted by CT }\end{array}$ \\
\hline $\begin{array}{l}\text { Laird et al. [18] } \\
\qquad 11 \text { weeks }\end{array}$ & $\begin{array}{l}28 \text { women (mean } \\
\text { age of } 20 \text { ) }\end{array}$ & $\begin{array}{c}3 \text { days a week } \\
\text { unspecified }\end{array}$ & $\begin{array}{l}\text { END training was } \\
\text { performed } 4 \text { hours } \\
\text { after RT } \\
3 \text { days a week } \\
\text { Sprint interval } \\
\text { training }\end{array}$ & Moderate & $\begin{array}{c}\text { CT did not interfere } \\
\text { with strength or power } \\
\text { gains }\end{array}$ \\
\hline McCarthy et al. [19] & Sedentary Males & $\begin{array}{l}3 \text { days a week; } 8 \\
\text { exercises; } 4 \text { sets; } 5-7 \\
\text { reps per set }\end{array}$ & $\begin{array}{c}3 \text { days a week } \\
\text { immediately after } \\
\text { strength training; } \\
\text { Cycle ergometer for } \\
50 \text { minutes }\end{array}$ & 3 days; moderate & $\begin{array}{l}\text { CT yielded similar } \\
\text { gains (substantial) } \\
\text { in strength as the } \\
\text { strength only group }\end{array}$ \\
\hline $\begin{array}{l}\text { Nelson et al. [14] } \\
20 \text { weeks }\end{array}$ & $\begin{array}{l}\text { Untrained healthy } \\
\text { men }\end{array}$ & $\begin{array}{c}4 \text { days a week } \\
\text { One RT exercise at } \\
\text { max effort, } 3 \text { sets of } 6\end{array}$ & $\begin{array}{l}30-60 \text { minutes on } \\
\text { ergometer at } 70 \%- \\
85 \% \text { max heart } \\
\text { rate. Performed } 10 \\
\text { minutes after RT }\end{array}$ & 4 ; moderate to high & $\begin{array}{l}\text { CT yielded similar } \\
\text { gains in strength as the } \\
\text { strength only group }\end{array}$ \\
\hline $\begin{array}{l}\text { Petros, Toubekis, \& } \\
\text { Platanou [15] } \\
8 \text { Weeks }\end{array}$ & Water polo players & $\begin{array}{c}\text { Twice a week } \\
85-90 \% \text { of } 1 \mathrm{RM} \\
4 \text { sets of } 5\end{array}$ & $\begin{array}{l}\text { Twice a week } \\
\text { Group } 1-4 \times 4 \text { min } \\
\text { of HIIT } \\
\text { Group } 2 \text { - } 10 \text { x } 100 \\
\text { meter swim }\end{array}$ & Low & $\begin{array}{l}\text { Maximal strength } \\
\text { was improved in both } \\
\text { groups indicating that } \\
\text { CT raining did not } \\
\text { interfere w/ strength. } \\
\text { Swim speed increases } \\
\text { were noted }\end{array}$ \\
\hline $\begin{array}{l}\text { Sale, MacDougall, \& } \\
\text { Jacobs [16] } \\
22 \text { Weeks }\end{array}$ & $\begin{array}{l}16 \text { participants } \\
\text { Mean age of } 44\end{array}$ & $\begin{array}{c}\text { Twice a week } \\
\text { Group } 1-3 \times 4 \text { at } 85- \\
90 \% 1 \mathrm{RM} \\
\text { Group } 2-3 \times 10 \text { at } \\
70 \%\end{array}$ & $\begin{array}{l}3 \text { days a week } \\
\text { Five } 3 \text { minute bouts } \\
\text { on a cycle ergometer } \\
\text { at a power output of } \\
90-100 \% \text { of VO2 }\end{array}$ & 3 days & $\begin{array}{l}\text { CT training did not } \\
\text { interfere with strength }\end{array}$ \\
\hline $\begin{array}{l}\text { Varela Sanz et al. [8] } \\
\qquad 8 \text { weeks }\end{array}$ & $\begin{array}{l}35, \text { predominately } \\
\text { men. Mean age } 21\end{array}$ & $\begin{array}{c}3 \text { sessions per week } \\
\text { Group 1-3-5 sets of } \\
10-12 \text { reps } \\
\text { Group } 2-3-5 \text { reps } \\
\text { of 5RM on Monday; } \\
\text { 2-4 sets of 15RM on } \\
\text { Fridays }\end{array}$ & $\begin{array}{l}\text { Group } 1 \text { - } 24-37 \text { at } \\
65-75 \% \text { of MAS } \\
\text { Group } 2-35-65 \\
\text { minutes of walking } \\
\text { at } 35-45 \% \text { of MAS \& } \\
\text { HIIT Sprint Sessions } \\
\text { at } 120 \% \text { MAS } \\
\text { *END work after RT } \\
\text { MAS = Max aerobic } \\
\text { speed }\end{array}$ & Moderate & $\begin{array}{l}\text { Both groups indicated } \\
\text { improvements in } \\
\text { bench press and squat. } \\
\text { Group } 2 \text { increased } \\
\text { jump capacity } \\
\text { output while Group } \\
1 \text { saw higher aerobic } \\
\text { improvements. }\end{array}$ \\
\hline $\begin{array}{l}\text { Wong et al. [9] } \\
\text { 8 Weeks }\end{array}$ & $\begin{array}{l}39 \text { Male Professional } \\
\text { Soccer Players }\end{array}$ & $\begin{array}{l}\text { Twice Weekly } \\
\text { Use intensities in the } \\
65-85 \% \text { range. Back } \\
\text { squat, high pull, jump } \\
\text { squat, and chin up. }\end{array}$ & $\begin{array}{c}\text { Twice Weekly } \\
16 \text { intervals of } 15 \\
\text { seconds sprints at } \\
120 \% \text { max aerobic } \\
\text { speed }\end{array}$ & Low & $\begin{array}{c}\text { Vertical jump (as } \\
\text { measure of power), } 10 \\
\text { sprint speeds and all } \\
\text { lifts went up. CT did } \\
\text { not interfere }\end{array}$ \\
\hline
\end{tabular}

\section{Scientific Explanation for CT Incompatibility}

Hawley [1] concluded that both strength training and hypertrophy training are attenuated by endurance work because the physiological processes are diametrically opposed. According to Hawley, muscle protein anabolism occurs when the rate of protein synthesis is greater than the rate of muscle protein degradation. This process is slow because "protein synthesis must exceed protein breakdown for an extended period (weeks to months)". Hawley attributed the attenuation to an interruption of intracellular signaling pathways (E.g. Phosphatidylinositol 3-kinase, rapamycin) ultimately causing a retardation of protein synthesis. 


\section{Running and Strength Interference}

A meta-analysis by Wilson 2012 examined the interference of aerobic and resistance exercise. Of the 21 studies and total of 422 effect sizes, the authors concluded that running had the strongest relationship to interference. "For moderator variables, resistance training concurrently with running, but not cycling, resulted in significant decrements in both hypertrophy and strength". Other studies support this finding [2-5]. Other studies do not support a strong correlation between interference of strength development and running based CT [6-9]. Based upon the scientific evidence, the effect of high speed sprinting and slower running on strength cannot be determined more favorable or negative.

\section{Cycling and Strength Interference}

Of the eight studies that used cycling as an endurance modality listed in Table 1, three of the studies indicated that END attenuated strength development $[3,5,10]$. No discernable inferences can be made based on speed or duration of these attenuations. However, in two cases the volume of the work was high, indicating that volume may be a more important determinant than mode of exercise.

\section{Volume and Strength Interference}

Five of the nine studies that indicated an interference effect exists between END training and strength training presented situations where the weekly training volume was high [35,10,11]. Bell et al. [10] engaged in both END and RT training six days a week by alternating RT and END days. Likewise, both Hennessy \& Watson [11] and Hickson [3] used an alternating RT and END schedule five days and six days of the week respectively. Also, using a daily alternating RT and END protocol, Karavirta et al. [5] had participants train at less frequency (4 days) but employed long duration exercise bouts (45-90 minutes). Jones et al. [4] cited the importance of accounting for total volume in CT.

High volumes of endurance training resulted in the inhibition of lower body strength, whereas low volumes did not. Lower body power was attenuated by high and low frequencies of endurance. High frequencies of endurance resulted in increased cortical responses to training. These data suggest that if strength development is the primary focus on a training intervention, frequency of endurance must be low. Not all examples of low volume CT experiences had positive outcomes [2,12] and not all high-volume studies resulted in negative outcomes $[13,14]$. However, several studies give great insight to exercise professionals when planning concurrent training periods. Higher volumes of endurance work may interfere with strength development and should be programmed carefully.

\section{Successful Concurrent Training}

a) Low Volumes: Whereas high exercise volumes have indicated a negative effect on CT, low to moderate volumes have shown to be beneficial in improving both strength qualities and aerobic qualities. Alves et al. [6] found success increasing strength and power measures in young children using same day training of RT and END protocols for two days a week. Davis et al. [7] indicated strength increases close to $20 \%$ by employing a three-day schedule of RT work and subsequent treadmill running. In a similar study that utilized a three-day workweek encompassing subsequent END work after RT, Gravelle and Blessing [10] indicated no strength interference effect. Petros, Toubekis and Platanou [15] combined high intensity maximal strength training (85-90\%) and low volume END work (32 total minutes per week) to increase strength and swim speed in water polo players. Similarly, Sale, MacDougall and Jacobs [16] programmed only 45 minutes of weekly END work and found little interference. Lastly, Wong et al. [17] studied professional male soccer players engaged in two days of RT and two days of END work that encompassed 16 high-speed interval sprints. All lifts including bench press, squat, jump squat, and high pull increased.

b) Strength before END: In addition to lower volume, successful outcomes were seen in studies where RT training was performed before END training. Both Laird et al. [18] and McCarthy, Agre, Graf, Pozniak and Vailas [19] had participants train three days a week and scheduled END work after RT; one group four hours after and another group immediately after respectively. Both groups saw no interference effect and realized positive strength adaptations. Even under high volume training, cases where RT precedes END work resulted in positive strength adaptations [14]. Varela Sanz, Tuimil, Abreu \& Boullosa [8] combined relatively low volumes of RT with subsequent volumes of END work and results indicated strength gains across all lifts. However, groups that underwent high volumes of END work did jump less high than the lower volume END group.

\section{Conclusion}

A lack of compelling evidence exists in the reviewed literature to make credible inferences about study length, mean age of population, and mode of END exercise (cycling vs running). These data support reducing volume during periods of CT. Two and three-week training days seem to have a greater frequency of success when compared to four, five, and six day studies. Though not all higher volume programs attenuated strength, many did, leaving exercise practitioners a warning to program volume in CT periods with caution. Also, scheduling RT work before END work has proven a successful method. These data are encouraging for exercise practitioners who need to augment simultaneous physical qualities to compete in their respective sports.

\section{References}

1. Hawley JA (2009) Molecular responses to strength and endurance training. Are they compatible? Applied Physiology Nutrition and Metabolism 34(3): 355-361.

2. Chtara M, Chaouachi A, Levin G, Chaouachi M, Chamari K et al. (2008) Effect of concurrent endurance and circuit resistance training sequence on muscular strength and power development. Journal of Strength and Conditioning Research 22(4): 1037-1045. 
3. Hickson R (1980) Interference of strength development by simultaneously training for strength and endurance. European Journal of Applied Physiology 45(2): 225-263.

4. Jones T, Howatson G, Russell M, French D (2013) Performance and neuromuscular adaptations following differing ratios of concurrent strength and endurance training. Journal of Strength and Conditioning Research 27(12): 3342-3351.

5. Karavirta L, Hakkinen A, Sillanpaa E, Garcia-Lopez D, Kauhanen A, et al. (2011) Effects of combined endurance and strength training on muscle strength, power, and hypertrophy in 40-67-year-old men. Scandinavian Journal of Medicine \& Science in Sports 21(3): 402-411.

6. Alves A, Marta C, Neiva H, Izquierdo M, Marque M (2016) Concurren training in prepubescent children: The effects of 8 weeks of strength and aerobic training on explosive strength and VO2max. Journal of Strength and Conditioning 30(7): 2019-2032.

7. Davis W, Wood D, Andrews R, Elkind, David W (2008) Concurrent training enhances athletes strength, muscle endurance, and other measures. Journal of Strength and Conditioning Research, 22(5): 1487-1502.

8. Varela Sanz A, Tuimil J, Abreu L, Boullosa D (2017) Does concurrent training intensity distribution matter. Journal of Strength and Conditioning Research 31(1): 181-195.

9. Wong P, Chaouachi A, Chamari K, Dellal A, Wisloff U (2010) Effect of preseason concurrent muscular strength and high-intensity interval training in professional soccer players. Journal of Strength and Conditioning Research 24(3): 653-660

10. Bell G, Syrotuik D, Martin T, Burnam R, Quinney H (2000) Effect on concurrent strength and endurance training on skeletal muscle properties and hormone concentrations in humans. European Journal of Applied Physiology 81(5): 418-427.

11. Hennessy L, Watson A (1994) The interference effects of training for strength and endurance simultaneously. Journal of Strength and Conditioning Research 8: 12-19.
12. Izquierdo M, Hakkinen K, Ibanez J, Kraemer W, Gorostiaga E (2005) Effects of combined resistance and cardiovascular training on strength, power, muscle cross-sectional area, and endurance markers in middleaged men. European Journal of Applied Physiology 94(1-2): 70-75.

13. Hakkinen K, Alen M, Kraemer W, Gorostiaga E, Izquierdo M, et al (2003) Neuromuscular adaptations during concurrent strength and endurance training versus strength training. European Journal of Applied Physiology 89(1): 42-52.

14. Nelson A, Arnall D, Loy S, Silveste L, Conlee R (1990) Consequences of combining strength and endurance training regimes. Physical Therapy 70(5): 287-294

15. Petros B, Toubekis A, Platanou T (2016) Concurrent strength and interval endurance training in elite water polo players. Journal of Strength and Conditioning Research 30(1): 126-133.

16. Sale D, MacDougall J, Jacobs I, Garner S (1990) Interaction between concurrent strength and endurance training. Journal of Applied Physiology 68(1): 260-270.

17. Wong P, Chaouachi A, Chamari K, Dellal A, Wisloff U (2010) Effect of preseason concurrent muscular strength and high-intensity interval training in professional soccer players. Journal of Strength and Conditioning Research 24(3): 653-660.

18. Laird R, Elmer D, Barberio M, Salom L, Lee K, et al. (2016) Evaluation of performance improvements after either resistance training or sprint interval-based concurrent training. Journal of Strength and Conditioning Research 30(11): 3057-3065.

19. McCarthy J, Agre J, Graf B, Pozniak M, Vailas A (1995) Compatibility of adaptive responses with combining strength and endurance training. Med Sci Sports Exercise 27(3): 429-436.

\section{Your next submission with Juniper Publishers will reach you the below assets}

- Quality Editorial service

- Swift Peer Review

- Reprints availability

- E-prints Service

- Manuscript Podcast for convenient understanding

- Global attainment for your research

- Manuscript accessibility in different formats

( Pdf, E-pub, Full Text, Audio)

- Unceasing customer service

Track the below URL for one-step submission https://juniperpublishers.com/online-submission.php 